Teologia i Moralność, volumen 12(2017), numer 1(21)

doi: 10.14746/tim.2017.21.1.10

FRANCISZKA ROUBO

Uniwersytet im. Adama Mickiewicza w Poznaniu

Wydział Teologiczny

\title{
Idea rodzicielstwa duchowego w życiu i twórczości Karola Wojtyły
}

To, co buduje główne przesłanie idei rodzicielstwa duchowego, kształtowało się w całym życiu Karola Wojtyły, poczynając od doświadczeń jego dzieciństwa, aż do posługi biskupiej. Rodzicielstwo duchowe jako pojęcie dosłowne występuje w jego twórczości sporadycznie, najczęściej przywoływane są przez autora najbliższe synonimy tego pojęcia, a mianowicie macierzyństwo i ojcostwo w znaczeniu duchowym i biologicznym bądź ujmowane rozdzielnie. Jednakże wywodząca się z tych pojęć, komentarzy i myśli Karola Wojtyły idea rodzicielstwa duchowego jest bardzo ważna i znajduje kontynuację w przepowiadaniu Jana Pawła II, gdyż łączy wiele ważnych tematów w nauczaniu Kościoła, które dotyczą między innymi powołania kobiety i mężczyzny, problemów rodziny, zagadnienia świętości, ewangelizacji oraz dzieł miłosierdzia.

Historia życia Karola Wojtyły obfituje w trudne, wręcz traumatyczne wydarzenia rodzinne, takie jak przedwczesna śmierć matki, siostry, brata, a także ojca. Osierocenie dodatkowo pogłębiły bolesne doświadczenia w czasie II wojny światowej ${ }^{1}$. W takich warunkach zainteresowania literackie i filozoficzne mogły wręcz odizolować młodego Karola Wojtyłę od ludzi. Stało się jednak inaczej - okazały się one zaczynem rozwoju człowieczeństwa przyszłego papieża, jego twórczości i działalności duszpasterskiej. Trudne doświadczenia dzieciństwa i młodości okazały się również inspiracją wczesnej poezji Karola Wojtyły. Wybitny psychiatra i psycholog XX wieku Viktor E. Frankl określa generację wojenną jako pokolenie zranione i naznaczone głębokim cierpieniem $^{2}$, szczególnie gdy doświadczyło ono wojny w czasie dzieciństwa

\footnotetext{
${ }^{1}$ Por. G. Weigel, Świadek nadziei: biografia papieża Jana Pawła II, Kraków 2000, s. 65- 66.

2 Por. V.E. Frankl, Homo patiens, Warszawa 1984, s. 82-83.
} 
lub wczesnej młodości, co miało miejsce w życiu Karola Wojtyły. Na traumę wojenną w życiu Karola Wojtyły nałożyły się doświadczenia reżimu komunistycznego w Polsce powojennej. W młodości jako ksiądz, a potem w latach dojrzałych już jako biskup Karol Wojtyła wielokrotnie miał styczność z takimi owocami totalitaryzmu jak celowe i zorganizowane niszczenie człowieka i rodziny. W czasie jego pracy dydaktyczno-naukowej na Katolickim Uniwersytecie Lubelskim władze wprowadziły aborcję na życzenie. Podstawowa wartość, jaką jest życie człowieka, została zagrożona nie przez wroga narodu, jak to się działo w czasie niedawno zakończonej wojny, ale przez dobrze zorganizowane służby medyczne, podporządkowane ideologii komunistycznej3 ${ }^{3}$. W takim klimacie ks. Karol Wojtyła jako naukowiec badał trudne problemy etyczne człowieka i rodziny. Rozwijał i pogłębiał, także w praktyce duszpasterskiej, główne myśli swojej rozprawy doktorskiej: Nauka o wierze wedlug św. Jana od Krzyża, w której jako centrum życia każdego chrześcijanina ukazał spotkanie z osobowym Bogiem przez wzajemne oddanie się, analogiczne do spotkania dwóch kochający się osób ${ }^{4}$. Działalność naukowo-dydaktyczna na Katolickim Uniwersytecie Lubelskim to dla Wojtyły także czas intensywnej współpracy z katolikami świeckimi, szczególnie w zakresie rozwiązywania ważnych problemów człowieka i rodziny. Liczne spotkania z nimi rozwijały u Wojtyły ogromną wyobraźnię intelektu, serca i ducha, co zaowocowało w przyszłości licznymi dokumentami i odważnymi inicjatywami papieża Jana Pawła II na rzecz człowieka i rodziny.

W niniejszym artykule najpierw omówione zostaną początki idei rodzicielstwa duchowego w twórczości poetyckiej Karola Wojtyły, następnie ukażemy rozwinięcie i umocowanie tej idei w jego późniejszej twórczości. W dalszej części artykułu podejmiemy rozważania dotyczące postawy bezinteresownego daru $\mathrm{z}$ siebie $\mathrm{w}$ kontekście idei rodzicielstwa duchowego oraz moralnego imperatywu wyzwania do określonej postawy i działania, które wynikają z rodzicielstwa duchowego.

\section{Początki idei rodzicielstwa duchowego w twórczości poetyckiej Karola Wojtyły}

Na wczesną twórczość Karola Wojtyły, wyrażoną głównie w poezji oraz w dramatach, miały wpływ ważne wydarzenia oraz spotkania czasów jego dzieciństwa i młodości. Niezwykle ważną osobą w życiu młodego Karola był jego ojciec kapitan Karol Wojtyła, który przekazał synowi swoisty instynkt

\footnotetext{
${ }^{3}$ Por. G. Weigel, Świadek nadziei: biografia papieża Jana Pawła II, dz. cyt., s. 184-185.

${ }^{4}$ Por. tamże, s. 115-116.
} 
ojcostwa. Młody Karol jako ksiądz i filozof pojmował to i rozwijał w kategoriach teologicznych: ,instynkt ojcostwa i odpowiedzialność ojcowska są pewnego rodzaju ikoną Boga i stosunku Boga do świata. Ojcostwo oznacza odrzucenie więzienia samolubstwa; ojcostwo oznacza bycie podbitym przez miłość" . Miłość i szacunek do ojca wdowca wyznaczyły moralny kierunek w życiu K. Wojtyły ${ }^{6}$. Jednakże moralna lekcja, jaką otrzymał syn od ojca, nie miała charakteru stoickiego, lecz chrześcijański - była to lekcja cierpienia przemienionego przez wiarę ${ }^{7}$. Ważną rolę w odkrywaniu i rozwoju duchowości ojcostwa młodego Karola Wojtyły odegrał także Jan Tyranowski, o którym później powiedział Jan Paweł II: „żył bardzo osobistym doświadczeniem Boga" i utwierdzał w przekonaniu, że świętość jest powołaniem każdego w Kościele ${ }^{8}$. Ten szczególny opiekun duchowy młodych, z wyuczenia księgowy, ale utrzymujący się z krawiectwa ${ }^{9}$, kształtował wrażliwość K. Wojtyły w kierunku duchowości św. Jana od Krzyża i św. Teresy Wielkiej. Jan Tyranowski zaszczepił w Wojtyle trwały szacunek dla duchowości karmelitańskiej ${ }^{10}$, szczególną cześć dla św. Józefa. Dla Karola Wojtyły Jan Tyranowski był także po śmierci jego ojca przyjacielem i przewodnikiem ${ }^{11}$. Napisał o nim później niezwykle ważne słowa: „Jan w całym słowa tego znaczeniu pracował nad naszymi duszami [...] chodziło mu o wydobycie z zasobów nadprzyrodzonych, o których wiedział, że istnieją w duszach, rzeczywistej postaci życia nadprzyrodzonego, życia, które przez łaskę staje się uczestnictwem w życiu Boga" ". Podejście Jana Tyranowskiego do życia wewnętrznego miało wymiar apostolski. Uczył swoich podopiecznych, że praktyka przebywania w obecności Boga winna prowadzić do intensywniejszego praktykowania w życiu służby bliźnim ${ }^{13}$.

Na kierunek zainteresowań oraz sposób poetyckiego postrzegania rzeczywistości młodego Karola Wojtyły miały wpływ także dzieła Cypriana Norwida, poety wolności wszelakiej, które go zafascynowały, mimo że nigdy publicznie na ten temat się nie wypowiada ${ }^{14}$. Tadeusz Szulc, autor jednej z wielu biografii Jana Pawła II, potwierdza zainteresowania K. Wojtyły romantycznym, narodowym poetą, pisząc, że „Norwid wolał «rzeczywistość» i «doś-

5 Tamże, dz. cyt., s. 62.

6 Por. tamże, s. 61.

${ }^{7}$ Por. tamże, s. 61-62.

8 Por. tamże, s. 84.

9 Por. tamże, dz. cyt., s. 81-82.

${ }_{10}$ Por. tamże, s. 84-85.

11 Por. T. Szulc, Papież Jan Pawet II: biografia, tłum. Z. Uhrynowska-Hanasz, M. Wroczyński, Warszawa 1999, s. 113.

12 Tamże, s. 108-109.

13 Por. tamże, s. 83.

14 Por. tamże, s. 78-79. 
wiadczenie życia», co było zbliżone do tez prezentowanych przez fenomenologię, która tak interesowała Wojtyłę" ${ }^{15}$. Obecny w poezji liryczny i intuicyjny ogląd świata, często wyprzedzający wiedzę i doświadczenie życiowe, również u młodego Karola Wojtyły otworzył horyzont jego przyszłych zainteresowań i działalności.

Czy można zatem znaleźć początkowy zarys idei „rodzicielstwa duchowego" w poezji Karola Wojtyły? Idea ta wyrasta z samej problematyki poezji K. Wojtyły, który w swojej twórczości literackiej zajmował się egzystencjalnym i filozoficznym znaczeniem cierpienia, powołania człowieka, wspólnoty ludzkiej oraz komentował zagadnienia i problemy związane ogólnie z rodzicielstwem człowieka, ojcostwem i macierzyństwem. Reprezentatywnymi przykładami takich wielosegmentowych utworów są: $M a t k a^{16}$, Dzieci $^{17}$, Uczestnictwo $^{18}$. Na szczególne podkreślenie zasługuje cykl utworów Uczestnictwo, gdyż akcentuje wielką rolę solidarności społecznej i odpowiedzialności za każdego spotkanego człowieka. W samym tytule oraz głównym przesłaniu tych utworów zawiera się zarys, ślad idei rodzicielstwa duchowego.

Jednakże w badaniu początków idei rodzicielstwa duchowego pragniemy szczególnie zwrócić uwagę na pierwszy rozbudowany tekst, a mianowicie esej Karola Wojtyły o znamiennym tytule Rozważanie o ojcostwie ${ }^{19}$. Znalazły się w nim uwagi o tym, czym jest promieniowanie ojcostwa. Refleksje autora, obejmujące problem samotności literackiego Adama w sytuacji odrzucenia cierpienia, jakie stwarza ryzyko miłości ${ }^{20}$, tworzą wielopoziomową interpretację tytułowego zagadnienia promieniowania ojcostwa. W podsumowaniu tego eseju Karol Wojtyła wypowiada myśl, która leży u podstaw poetyckiego widzenia idei rodzicielstwa duchowego: „Przyjąć w siebie promieniowanie ojcostwa, to nie znaczy tylko «stać się ojcem» - to znaczy o wiele bardziej «stać się dzieckiem» (stać się synem). Będąc ojcem wielu, wielu ludzi, muszę być dzieckiem: im bardziej ojcem, tym bardziej dzieckiem"21. Ten kierunek refleksji skoncentrowanej wokół tematu promieniowania ojcostwa, a w konsekwencji także wokół idei rodzicielstwa duchowego, będzie rozwijany w dalszej twórczości poety, filozofa oraz teologa-kapłana i biskupa.

Bezpośrednią kontynuacją myśli przewodniej utworu pt. Rozważania o ojcostwie jest napisane później przez ks. Karola Wojtyłę misterium Promienio-

15 T. Szulc, Papież Jan Pawet II: biografia, s. 78.

${ }^{16}$ K. Wojtyła, Poezje i dramaty, wybór: M. Skwarnicki, J. Turowicz, red. J. Okoń, Kraków 1987, s. 36.

${ }^{17}$ K. Wojtyła, Poezje wybrane, Warszawa 1987, s. 67.

18 Tamże, s. 83.

${ }^{19}$ Por. K. Wojtyła, Poezje i dramaty, dz. cyt., s. 68.

${ }^{20}$ Por. tamże, „Jakże ja mogłem stać się synem. Nie chciałem nim być. Nie chciałem przyjąć cierpienia jakie stwarza ryzyko miłości” - s. 71.

${ }^{21}$ Por. tamże, s. 71. 
wanie ojcostwa ${ }^{22}$, które rozwija zagadnienie głębi ludzkiego rodzicielstwa ugruntowanego w Bogu. Znamienny jest wywód autora na temat zaszczepienia ludzkiego rodzicielstwa w duszy. Analizując swoją samotność, literacki Adam stwierdza: „Przecież mogłeś mnie pozostawić w sferze samej płodności (jakoś bym się pogodził z przyrodą) - nie stawiając mnie w głębi tego ojcostwa, któremu nie umiem podołać! Dlaczego zaszczepiłeś je na gruncie mojej duszy? Czyż nie wystarczyło, że masz je w sobie?"23. Powyższy rozbudowany wielowątkowo przez autora tekst jednoznacznie pokazuje poszukiwania kierujące go do duchowego ojcostwa człowieka.

Misterium K. Wojtyły Promieniowanie ojcostwa podkreśla powiązanie duchowego macierzyństwa z ojcostwem duchowym, czyli także ,zaszczepionego na gruncie duszy" każdej kobiety ${ }^{24}$. Snując refleksje na temat macierzyństwa, K. Wojtyła podkreśla jednocześnie, że ten wymiar cierpienia zna tylko kobieta. „Kobieta wie o rodzeniu niepomiernie więcej niż mężczyzna”"25. Młody ksiądz Karol Wojtyła jako poeta $\mathrm{z}$ wielką empatią postrzegał macierzyństwo i ojcostwo, nie stroniąc od perspektywy właściwej doświadczeniom życiowym kobiety. Powyższe spostrzeżenia K. Wojtyła rozwinął w przesłaniu swojego dzieła Miłość i odpowiedzialność. Wcześniejsze doświadczenia oraz szczególna umiejętność wejścia w przeżycia drugiego człowieka ${ }^{26}$ dały początki prezentacji idei rodzicielstwa duchowego człowieka w jego późniejszej twórczości literackiej.

Wyraźne początki idei rodzicielstwa duchowego znalazły się w dramatach przyszłego papieża. Stanowią one niepowtarzalny fenomen w dorobku literackim Karola Wojtyły ${ }^{27}$, który w ciągu 25 lat, w czasie od młodości do pełnionego biskupstwa, napisał sześć utworów dramaturgicznych. Pierwsze: Dawid (tekst tego utworu zaginą), Hiob, Jeremiasz i Brat naszego Boga (pierwsza wersja), powstały w czasie II wojny światowej, kiedy ich autor był studentem polonistyki na tajnym Uniwersytecie Jagiellońskim i jednocześnie robotnikiem $^{28}$. Natomiast drugą wersję Brata naszego Boga, Przed sklepem jubilera, Promieniowanie ojcostwa Karol Wojtyła napisał już jako kapłan, biskup i arcybiskup krakowski.

Skupimy się na dwóch utworach. Karol Wojtyła wprowadza w nich czytelnika w obszar dociekań egzystencjalnych oraz moralnych, które składają

22 Tamże, s. 233.

${ }^{23}$ K. Wojtyła, Poezje i dramaty, dz. cyt., s. 235.

24 Por. tamże, s. 239.

25 Tamże, s. 239.

${ }^{26}$ Por. G. Weigel, Świadek nadziei, dz. cyt., s. 142.

27 Por. J. Machniak, Bóg i człowiek w poezjach K. Wojtyty - cz. I, http://www.janmachniak.p1/ index.php/moje-wykłady-2/53-bog-i-cz.I..., [dostęp: 21.09.2016], s. 1.

${ }^{28}$ Por. tamże, s. 1. 
się na początki idei rodzicielstwa duchowego. Są to Hiob skoncentrowany na kwestii cierpienia oraz Brat naszego Boga podejmujący kwestię chrześcijańskiego miłosierdzia.

Dramat Hiob uderza głębią myśli młodego, dwudziestoletniego autora, który w słowie Bożym szukał zrozumienia swojego cierpienia i jednocześnie nadziei na przyszłość. W ujęciu Karola Wojtyły cierpienie nie jest zamierzone przez Boga, ale zostało przez Niego dopuszczone jako konsekwencja wolnej woli człowieka. Nawet jeśli jest ono złem, które niszczy człowieka, dzięki zjednoczeniu z Chrystusem i Jego ofiarą Krzyża może stać się środkiem, który przemienia człowieka i pozwala mu uczestniczyć w chwale Jezusa. Bóg jest obecny w cierpieniu. Nie zostawia człowieka w samotności ${ }^{29}$. Potwierdzeniem przewodniej idei dramatu jest Epilogos z głównym przesłaniem zawartym w słowach: „Oto cierpienie, co gruntuje - oto cierpienie, co przemienia, co Nowy Zakon w sercu kuje, jak nowy dzień stworzenia [...]”30. Ta ważna chrześcijańska myśl dramatu o ubogacającym cierpieniu będzie towarzyszyła całej późniejszej twórczości poetyckiej K. Wojtyły.

Ma ona również ważne miejsce w idei rodzicielstwa duchowego. Rodzicielstwo biologiczne w perspektywie kobiety, nie tylko matki, łączy się z cierpieniem danym jej, aby mogła rozwijać szczególną empatię, która pomaga jej współuczestniczyć w rozwoju fizycznym i duchowym nowego człowieka. Jest również związane z pełnieniem odpowiedzialnej ojcowskiej roli przez mężczyznę, szczególnie w wymiarze społecznym. Podobnie w rodzicielstwie duchowym obecne jest współuczestniczenie w wyzwalaniu człowieka zranionego, często okaleczonego fizycznie i duchowo, czemu towarzyszy cierpienie.

W kolejnym dramacie Brat naszego Boga - „Odkrywanie oblicza Chrystusa w ubogich"31, młody Albert Chmielowski znalazł potwierdzenie dla swojej decyzji porzucenia sztuki, by ratować poranionego i dotkniętego grzechem człowieka. Znamienne są słowa, odkrycie bohatera dramatu, przyszłego brata Alberta, że ma się stać jako: „narzędzie ich przybrania za synów”32. Dramat zawiera ślady poszukiwania przez autora odpowiedzi na pytanie, czym jest miłosierdzie. Karol Wojtyła prowadzi czytelnika do rozumienia rodzicielstwa duchowego jako aktywnej odpowiedzi na ludzką nędzę. Główny bohater utworu, brat Albert Chmielowski, poważnie wątpi, czy układ ludzkiej nędzy odpowiada układowi społecznej kary za nią ${ }^{33}$. Dialogi dramatu, przemyślenia głównego bohatera dotykają najgłębszych zagadnień istoty miłosierdzia Boże-

29 Por. J. Machniak, Bóg i człowiek w poezjach K. Wojtyty - cz. I, dz. cyt., s. 2.

${ }^{30}$ K. Wojtyła, Poezje i dramaty, dz. cyt., s. 324.

31 Por. J. Machniak, Bóg i człowiek w poezjach K. Wojtyły - Jana Pawła II - cz. V, http://www. janmachniak.pl/index.php/moje-wykłady/53-bog-i-cz..., [dostęp: 21.09.2016], s. 3.

32 Por. K. Wojtyła, Poezje i dramaty, dz. cyt., s. 150.

33 Por. tamże, s. 129. 
go. W tym szczególnym utworze Karola Wojtyły krystalizujące się rodzicielstwo duchowe przyszłego brata Alberta, dzięki bardzo wymownemu nazwaniu jego przyszłej misji jako ,przybrania za synów ${ }^{34}[\ldots]$ rzeszy wydziedziczonej”, złączone jest z przeżyciem i odkrywaniem istoty miłosierdzia Bożego. Wątki występujące w dramacie Brat naszego Boga, w tym także rodzicielstwo duchowe osadzone w idei miłosierdzia Bożego, są zapowiedzią tematów i zagadnień, które zostały rozwinięte i znalazły kontynuację w nauczaniu Jana Pawła II. Padają tu sugestywne słowa określające tych, którzy potrzebują duchowego „usynowienia”, to „rzesza wydziedziczona”35. Bohater dramatu w sposób wyjątkowy rozumie postulat „bratania się z dziadami”. Czyż nie będzie on miał bardzo praktycznego przełożenia w zaleceniach szeroko rozumianej opieki społecznej, troski wyrażanej przez różnorodną adopcję dziecka, a także w odpowiedzialności za każdego człowieka w przyszłym nauczaniu Jana Pawła II?

\section{Rozwinięcie i umocowanie idei rodzicielstwa duchowego w późniejszej twórczości Karola Wojtyły}

Odbudowanie fundamentów życia moralnego było głównym problemem, przed którym stanął Karol Wojtyła, młody doktor teologii moralnej, a następnie biskup i pracownik naukowy oraz doświadczony duszpasterz młodzieży akademickiej i pracowników służby zdrowia ${ }^{36}$. Już na początku swojej drogi intelektualnego rozwoju, w czasie studiów na Angelicum w Rzymie, spotykał niekwestionowanego mistrza neoscholastyki, którym był o. Reginald Garrigou-Lagrange OP, promotor jego pracy doktorskiej, poświęconej zagadnieniu rozumienia wiary u św. Jana od Krzyża ${ }^{37}$. Rozprawa Wojtyły podkreślała osobowy charakter spotkania z Bogiem dostępnego nie tylko mistykom, spotkania stanowiącego centrum życia każdego chrześcijanina. Bardzo ważne jest to, że rozprawa umacniała $\mathrm{w}$ jej autorze przekonanie o niezbywalnej godności osoby ludzkiej ${ }^{38}$.

W klimacie takich spotkań i poszukiwań oraz dociekań naukowych biskup Karol Wojtyła rozwijał swoją twórczość intelektualną, którą tak charakteryzuje jeden z ważniejszych komentatorów i biografów Karola Wojtyły, Geor-

34 „Przybranie, przysposobienie to synonim słów: adoptować, usynowić, skoligować się, spokrewnić się [...]" - Stownik synonimów, red. A. Dąbrówka, E. Geller, R. Turczyn, Warszawa 1996, s. 120.

${ }^{35}$ Por. K. Wojtyła, Poezje i dramaty, dz. cyt., s. 126.

${ }^{36}$ Por. G. Weigel, Świadek nadziei, dz. cyt., s. 166.

37 Por. tamże, s. 114-115.

38 Por. tamże, s. 116. 
ge Weigel: „Praca profesora Karola Wojtyły jako filozofa, podobnie jak jego działalność literacka jako poety i dramaturga, rozwijała się w harmonii z jego pracą kapłańską"39. Na jego pracę intelektualną miały wpływ doświadczenia osobiste i duszpasterskie. $Z$ fenomenologii zaczerpnął metodę dociekań naukowych, by docierać do pełni rzeczywistości i widzieć rzeczy takimi, jakimi $\mathrm{są}^{40}$. Staranna analiza uczuć moralnych, zwłaszcza empatii i sympatii, zalecana w metodzie badań naukowych Maxa Schelera, z której skorzystał K. Wojtyła, zakładała konieczność spotkania z drugim człowiekiem ${ }^{41}$.

Jedną z takich syntez wielowymiarowego życia była pierwsza książka biskupa Karola Wojtyły Miłość i odpowiedzialnośćc ${ }^{2}$. Dzieło to jest pogłębionym spojrzeniem na miłość człowieka. Karol Wojtyła przedstawił w nim „stanowisko Kościoła w sposób, który mógł zostać usłyszany i włączony w kulturowy klimat, w którym termin «naturalny» staje się kategorią moralnej, a nawet duchowej siły"43. W omawianej książce można znaleźć rozwinięcie idei rodzicielstwa duchowego $\mathrm{w}$ naturalnym powiązaniu $\mathrm{z}$ rodzicielstwem biologicznym, choć nie tylko.

Natomiast traktat filozoficzny Karola Wojtyły Osoba i czyn zatrzymujący się nad naturą ludzkiego doświadczenia wykazuje, że w moralnym działaniu umysł, duch i ciało łączą się w jedności osoby ${ }^{44}$. W tym dziele autor ukazuje filozoficzne umocowanie idei rodzicielstwa duchowego, ponieważ w wolnym wyborze dobra i prawdy możemy rozpoznać transcendencję osoby ludzkiej, która jednocześnie otwiera nas na sprawy duchowe, w tym także na rodzicielstwo duchowe. To właśnie wybory moralne oraz ich rzeczywiste konsekwencje kształtują osobę. Podjęcie moralnego wyzwania w czynie i postawie osoby jest podstawą idei rodzicielstwa duchowego. „Przekraczam siebie, wzrastam jako osoba, realizując moją wolność i uzgadniając ją z dobrem i prawdą" 45 . Przekraczam siebie, gdy nie zatrzymuję się tylko na rodzeniu biologicznym, tylko na mojej rodzinie, wówczas przeżywam uczestnictwo i solidarność wielkiej rodziny ludzkiej.

\footnotetext{
39 G. Weigel, Świadek nadziei, dz. cyt., s. 183.

40 Por. tamże, s. 167.

${ }^{41}$ Por. tamże, s. 169.

42 Por. tamże, s. 183.

43 Tamże, s. 188.

${ }^{44}$ Por. tamże, s. 226-227.

45 Tamże, s. 226.
} 


\section{Bezinteresowny dar $\mathrm{z}$ siebie $w$ kontekście idei rodzicielstwa duchowego}

Głównym tematem dzieła Karola Wojtyły Miłość i odpowiedzialność jest zagadnienie miłości odpowiedzialnej. Wszak to właśnie osoba w swym czynie i poprzez niego staje się tejże miłości odpowiedzialnej podmiotem i adresatem i sama pisze swoją historię miłości albo jej negację, a przez to historię swego spełnienia lub niespełnienia ${ }^{46}$. W komentarzach do tego dzieła, które napisał George Weigel, podkreślona została szczególnie kwestia postrzegania miłości w jej najpełniejszej odsłonie jako bezinteresownego daru z siebie, czyli miłości przeżywanej w perspektywie serca i ciała kobiety ${ }^{47}$. Taki kontekst to swoiste novum, choć w teologii życia wewnętrznego, m.in. w bliskiej autorowi mistyce św. Jana od Krzyża, znane jest widzenie miłości i zjednoczenia duszy z Bogiem w pełnym oblubieńczym oddaniu, gdzie dusza człowieka jest oblubienicą Boga ${ }^{48}$. Karol Wojtyła w kolejnych odsłonach Miłości i odpowiedzialności dowodzi, że ów bezinteresowny dar z siebie wbudowany jest w ludzką kondycję. Tenże przymiot, któremu autor nadał doniosłe znaczenie, szczególnie wpisuje się w ideę rodzicielstwa duchowego i rozwija się w niej.

Analizowany traktat o człowieku na różnych poziomach przedstawia zasadniczą odmienność ludzkiej prokreacji od zwierzęcej. W oczywisty sposób pokazuje to, że przymiotem ludzkiej miłości jest „,bezinteresowny dar z siebie”. Autor dopełnił tę oczywistość stwierdzeniem: „Moralność seksualna wynika nie tylko stąd, że osoby mają świadomość celowości życia seksualnego, ale również stąd, że mają świadomość, iż są osobami. Z nią też łączy się cały moralny problem używania jako przeciwieństwa miłowania" ${ }^{\text {"49 }}$. Kontynuując i pogłębiając te myśli, stwierdził:

„Miłość nie jest tylko przyrodniczą czy nawet psycho-fizjologiczną krystalizacją popędu seksualnego, lecz jest czymś zasadniczo od niego różnym. Chociaż bowiem wyrasta i krystalizuje się na jego podłożu, w orbicie warunków wytworzonych przez ten popęd w psycho-fizjologicznym życiu konkretnych ludzi, to jednak kształtuje się dzięki aktom woli na poziomie osoby ${ }^{50}$.

Wykazując inność prokreacji ludzkiej, autor podkreślił jej osobowy charakter. Karol Wojtyła, charakteryzując ludzką miłość, miłowanie nazwał formą

${ }^{46}$ Por. K. Wojtyła, Miłość i odpowiedzialność, dz. cyt., s. 10.

47 Por. G. Weigel, Świadek nadziei, dz. cyt., s. 183-188.

48 Por. R. P. Hardy, Święty Jan od Krzyża czlowiek i mistyk, thum. J. Kaszubowska, Sandomierz 2006, s. 135-136.

${ }^{49}$ K. Wojtyła, Miłość i odpowiedzialność, dz. cyt., s. 35.

50 Tamże, s. 49. 
uszczęśliwiania drugiej osoby i w ten sposób odsłonił „boski rys miłości”51. To trochę poetyzujące określenie wprowadza jednoznacznie miłość człowieka w wymiar duchowej tajemnicy. Tak rozumiana miłość może odradzać człowieka oraz dawać mu poczucie bogactwa, wewnętrznej płodności i twórczości ${ }^{52}$.

Myśl o bezinteresownym darze z siebie w miłości przeżywanej przez człowieka potwierdza jej osobowy charakter i odrzuca używanie drugiego człowieka, tym samym biologiczna przestrzeń człowieka otwiera się na transcendencję osoby. Jednocześnie rodzenie biologiczne lub potencjalna możliwość rodzenia przeżywana $\mathrm{w}$ wolności osoby otwiera także na rodzenie $\mathrm{w}$ przestrzeniach ducha. Karol Wojtyła, ukazując godność życia swoją naturą, połączył je z życiem duchowym. Za szczególny łącznik pomiędzy naturą i duchem człowieka uznawał „bezinteresowny dar z siebie”, gdyż wyzwala on duchową aktywność, także w zakresie rodzenia.

Warto podkreślić, że już na kartach dzieła Miłość i odpowiedzialność przyszły papież zaakcentował to, że ,[...] pełny duchowy rozwój osoby ludzkiej stanowi owoc wychowania" ${ }^{33}$. Rozwijając tę myśl, Karol Wojtyła dodał: „Wychowanie to twórczość o przedmiocie jak najbardziej osobowym [...] stanowi tworzywo dla wychowawców, tworzywo, po które winna sięgać ich miłość" 54 . Podsumowując tę refleksję, stwierdził: „Bóg sam bierze najwyższy udział w tworzeniu ludzkiej osobowości w zakresie duchowym, moralnym, ściśle nadprzyrodzonym" 55 . Istotne są również związane ściśle z rodzicielstwem słowa: „Chodzi o to, że nie wystarczy tylko rodzić dzieci, trzeba je później utrzymywać i wychowywać" 56 . Owo rodzenie duchowe jest zadaniem całej rodziny oraz wychowawców i nauczycieli, uzyskuje społeczny zasięg, wychodzi poza rodzinę.

W traktacie Miłość i odpowiedzialność K. Wojtyła dzięki zastosowaniu fenomenologicznej metody prezentacji miłości i odpowiedzialności w relacjach kobiety i mężczyzny oraz relacji człowieka do Boga stwierdził: „Proces integracji miłości opiera się na pierwiastku duchowym w człowieku, na wolności i prawdzie" "57. Następnie dodał: „Miłość jest zawsze jakąś sprawą wnętrza i sprawą ducha" 58 . Skoro tak, to automatycznie rodzenie jako jej owoc ma wymiar nie tylko biologiczny, ale i duchowy. Rozwijając powyższe stwierdzenie w podsumowaniu Miłości i odpowiedzialności, w rozdziale „Sprawiedliwość

51 Tamże, s. 122.

52 Por. tamże, s. 123.

53 K. Wojtyła, Miłość i odpowiedzialność, dz. cyt., s. 54.

54 Tamże.

55 Tamże.

56 Tamże, s. 62.

57 Tamże, s. 105.

58 Tamże. 
względem Stwórcy”, Karol Wojtyła wskazał na wagę i znaczenie rodzicielstwa duchowego w życiu człowieka: „Ojcostwo i macierzyństwo w świecie osób stanowczo nie ogranicza się do funkcji biologicznej, do przekazywania życia. [...] Ojcostwo i macierzyństwo w świecie osób to znamię szczególnej doskonałości duchowej. Polega ona zawsze na jakimś «rodzeniu» w sensie duchowym, na kształtowaniu dusz" 59 .

Z pojęcia „rodzenia w sensie duchowym” możemy bezpośrednio wyprowadzić ideę rodzicielstwa duchowego wpisaną w kondycję osoby ludzkiej. Karol Wojtyła rozwinął ideę rodzicielstwa duchowego, opisując miłość jako immanentną część natury człowieka, co znalazło wyraz w stwierdzeniu. „Ojcostwo i macierzyństwo duchowe jest cechą charakteryzującą dojrzałą wewnętrzną osobowość mężczyzny i kobiety"60. Bezinteresowny dar z siebie to owoc wielopoziomowej pracy i starań tak mężczyzn, jak i kobiet, rozwijane konsekwentnie duchowe ojcostwo i duchowe macierzyństwo pomaga w osiągnięciu dojrzałości osobie ludzkiej. Karol Wojtyła podkreślał, że to duchowe ojcostwo jest o wiele bardziej podobne do macierzyństwa duchowego niż ojcostwo cielesne do cielesnego macierzyństwa ${ }^{61}$. Potwierdza to przykład świętych wszystkich stanów życia i powołań, których dojrzałości wewnętrznej kwestionować raczej nie możemy.

Uwieńczeniem traktatu K. Wojtyły Miłość i odpowiedzialność jest niejako esencja idei rodzicielstwa duchowego zakorzeniona i umocowana w przesłaniu „bezinteresownego daru z siebie”, w wyjątkowy sposób wyrażana w końcowych fragmentach dzieła, w rozdziale na temat terapii dotyczącej etycznych aspektów seksuologii. Autor dowodzi, że każda działalność wychowawcza bądź naprawcza będzie prowadzić do właściwego celu, jeżeli będzie rzetelnie osadzona $\mathrm{w},,[. .$.$] obiektywnej wizji osoby oraz jej naturalnego i nadnatural-$ nego powołania do miłości" ${ }^{2}$. Owo nadnaturalne powołanie do miłości może realizować się poprzez „bezinteresowny dar z siebie” małżonków, a także osób bezżennych, w bardzo pojemnej w zadania idei rodzicielstwa duchowego.

\section{Podjęcie moralnego wyzwania w czynie i postawie fundamentem rodzicielstwa duchowego}

Ogólniejsza konkluzja rozprawy habilitacyjnej Karola Wojtyły pt. Ocena możliwości zbudowania etyki chrześcijańskiej przy założeniach Maxa

\footnotetext{
59 Tamże, s. 232.

${ }^{60}$ K. Wojtyła, Miłość i odpowiedzialność, dz. cyt., s. 232.

${ }^{61}$ Por. tamże, s. 232.

${ }^{62}$ Por. tamże, s. 255.
} 
Schelera miała decydujące znaczenie dla rozwoju jego filozoficznej drogi ${ }^{63}$, gdyż ambicją K. Wojtyły było zbudowanie naukowego pomostu pomiędzy klasyczną etyką św. Tomasza z Akwinu a etyką personalistyczną w wydaniu M. Schelera ${ }^{64}$. Zdaniem Wojtyły, system M. Schelera nie nadaje się do naukowej interpretacji etyki chrześcijańskiej, może jednak stanowić pomoc metodologiczną w próbach jej całościowego opracowania ${ }^{65}$. Powyższą konkluzję zastosował w badaniach antropologicznych, w traktacie filozoficznym Osoba i czyn. Zastosowana $\mathrm{w}$ nim metoda fenomenologiczna zaczerpnięta $\mathrm{z}$ filozofii Maxa Schelera pomogła autorowi przedstawić szeroką perspektywę czynu i postawy osoby. Wszechstronna analiza wszystkich aspektów przedmiotu chroni przed subiektywizmem w ocenie moralnej osoby i jej czynu, który może rozwinąć się ,przy okazji zbyt ciasnego i jednostronnego obiektywizmu" $" 66$.

Dzieło K. Wojtyły Osoba i czyn jest świadectwem rzetelnej antropologii, pogłębieniem teorii osoby ludzkiej i wizji samego czynu. W uwagach wstępnych do jednego z wydań tegoż dzieła ${ }^{67}$ włoski filozof, jeden z najbardziej wnikliwych komentatorów myśli filozoficznej K. Wojtyły, Rocco Buttiglione podkreśla ogromne znaczenie tej książki, zaznaczając, że przedmiotem tego antropologicznego traktatu jest istota działania człowieka, natura ludzkiego doświadczenia, a także sam człowiek. Traktat filozoficzny biskupa Karola Wojtyły, zaangażowanego szczególnie w duszpasterstwo środowisk studenckich oraz medycznych, jest także odpowiedzią na potrzebę ożywienia chrześcijańskiego humanizmu, który prawdę o osobie ludzkiej odnajduje w osobie Jezusa Chrystusa ${ }^{68}$.

W poszukiwaniu filozoficznego kontekstu idei rodzicielstwa duchowego należy wyeksponować przedstawione w dziele różne aspekty duchowego pierwiastka osoby ludzkiej, które bezpośrednio składają się na ideę rodzicielstwa duchowego. W podrozdziale o znamiennym tytule: „Transcendencja osoby a duchowość człowieka”, Karol Wojtyła stwierdził: „Treścią przeżycia duszy jest wszystko to co [...] składa się na transcendencję osoby w czynie, a więc powinność, odpowiedzialność, prawdziwość, samostanowienie, świadomość $[\ldots]^{\prime 69}$.

${ }^{63}$ Por. G. Weigel, Świadek nadziei, dz. cyt., s. 170.

${ }^{64}$ Por. Działalność naukowa Karola Wojtyły - Centrum Myśli Jana Pawła II..., http://www. centrumjp2.p1, [dostęp: 23.09.2015], s. 3.

65 Tamże, s. 3.

${ }^{66}$ Por. K. Wojtyła, Osoba i czyn oraz inne studia antropologiczne, red. T. Styczeń, W. Chudy, J.W. Gałkowski i in., Lublin 2000, s. 106.

${ }^{67}$ Por. tamże, s. 14.

${ }^{68}$ Por. G. Weigel, Kres i poczatek, tłum. M. Romanek, Kraków 2012, s. 16.

${ }^{69}$ K. Wojtyła, Osoba i czyn, dz. cyt., s. 228. 
Według autora samostanowienie, czyli wolność, domaga się nieraz działania w imię prawdy o dobru, co może się kłócić z doraźnym odczuciem osoby $^{70}$. Prawdziwość oraz świadomość tworzą klimat prawdy o dobru. Do powyższych stwierdzeń doprowadziła autora wnikliwa analiza pojęcia i znaczenia sumienia w życiu osób: „Funkcja sumienia polega na określeniu prawdziwego dobra w czynie i na ukształtowaniu odpowiedniej do tego dobra powinności"71. Powinność, odpowiedzialność, samostanowienie są to oczywiste przymioty osoby podejmującej czyn, działanie na drodze wyboru dokonanego przez osobę, także wyboru moralnego. „Spełniając czyn, człowiek spełnia w nim siebie, staje się jako człowiek - jako osoba - dobrym lub złym"72. Działanie osoby zawsze jest zdeterminowane zastaną sytuacją, jest też osoba tą sytuacją zdeterminowana, jednakże jest w stanie przekroczyć te uwarunkowania mocą (wolnego wyboru - mogę - nie muszę - chcę ${ }^{73}$ ) posłuszeństwa prawdzie. Przez wolne działanie osoba urzeczywistnia samą siebie, spełnia swe przeznaczenie i staje się bardziej (o)sobą ${ }^{74}$.

Kolejnym obszarem zagadnień zawartym w podrozdziale traktatu, z których może czerpać idea rodzicielstwa duchowego, jest „Integracja osoby w czynie jako klucz zrozumienia psychosomatycznej jedności człowieka"75. Prawidłowe rozumienie owej jedności zakłada wcześniejsze już ujęcie transcendencji oraz integracji osoby w czynie. „Osoba, która przez czyn się ujawnia, przenika niejako i ogarnia zarazem całą psycho-somatyczną strukturę własnego podmiotu" "76. Czyn dookreśla osobę, a wolny wybór oraz konsekwencja w działaniach i postawach jest także dowodem na jej transcendencję, duchowy charakter. Podobnie jak miłość nie jest tylko rzeczywistością naturalną, czyn jest także przejawem transcendencji osoby ludzkiej.

Znaczący dla idei rodzicielstwa duchowego okazuje się pogląd autora, że człowiek w pełni odkrywa samego siebie wyłącznie w relacji do drugiego człowieka $^{77}$. To właśnie czyn, który podejmuje osoba, oddziałuje najmocniej na drugiego. Działania oraz postawy osoby ludzkiej przejawiają się także w jej uczestnictwie w wydarzeniach społecznych, nie tylko w spotkaniu z drugim, ale także w spotkaniu z większymi wspólnotami, społecznościami i grupami. W tego rodzaju uczestnictwie, w solidarności społecznej, odkrywamy wyraźne cechy rodzicielstwa duchowego takie, jak: dzielenie się swoim wnę-

\footnotetext{
70 Por. tamże, s. 275.

71 K. Wojtyła, Osoba i czyn, dz. cyt., s. 199.

72 Por. K. Wojtyła, Osoba i czyn, dz. cyt., s. 199.

73 Por. tamże, s. 17.

74 Por. tamże.

75 Tamże, s. 236.

76 Tamże, s. 338.

77 Por. tamże, s. 21-23.
} 
trzem z drugim człowiekiem, „miłość”, która nie jest tylko sentymentem, jest natomiast odpowiedzią na wartość osoby drugiego i decyzją współdziałania na rzecz jej urzeczywistniania ${ }^{78}$.

Kontynuując charakteryzowanie uczestnictwa w traktacie Osoba i czyn, K. Wojtyła przedstawia obszerne omówienie konformizmu jako postawy nieautentycznej, która wskazuje na brak zasadniczej solidarności, a równocześnie unikanie sprzeciwu. Ucieczka przed podjęciem wezwania moralnego przez człowieka - konformizm - niesie z sobą raczej ,jednolitość”, nie jedność ${ }^{79}$. Rozwijając tę ważną myśl, autor dodaje, że sytuacja konformistyczna zarówno osobie, jak i wspólnocie, przynosi niepowetowane szkody, „gdyż normy moralne wzrastają w nas poprzez moralne czyny" ${ }^{\prime 0}$. Kontynuując myśl autora, warto zauważyć, że poprzez unikanie podjęcia moralnych czynów, społeczeństwo, wspólnota zatraca swoją jedność. To myśl bardzo ważna, dotyka bowiem bezpośrednio istoty idei rodzicielstwa duchowego w wymiarze społecznym.

Intelektualna refleksja rozwinięta w rozdziale „Uczestnictwo” traktatu Osoba i czyn stwarza kontekst dla idei rodzicielstwa duchowego przeżywanego i realizowanego przez konkretną osobę w jej psychosomatycznych ograniczeniach i transcendencji, wyrażanego w konkretnym czynie moralnym: ,[...] tylko w dobru moralnym osoba spełnia siebie, zło jest zawsze jakimś niespełnieniem"81. To myśl o bardzo dużym znaczeniu dla zrozumienia idei rodzicielstwa duchowego, gdyż bezpośrednio wskazuje na siłę dobra i jego zwycięstwo już w momencie wyboru moralnego, a tym właśnie jest każdy czyn podyktowany realizacją idei rodzicielstwa duchowego. „Przykazanie miłości a odsłonięcie korzeni alienacji” to finalny tekst traktatu zamykający część ostatnią pt. „Uczestnictwo”. Otwiera on wymiar refleksji społecznej. Zdaniem autora, przykazanie „będziesz miłował” określa właściwą miarę zadań i wymagań, jakie muszą sobie postawić „wszyscy ludzie - osoby i wspólnoty - aby całe dobro działania i bytowania «wspólnie $\mathrm{z}$ innymi» mogło się prawdziwie urzeczywistnić" 82 . W świetle pogłębionej definicji autora uczestnictwo, a ściślej jego rdzeń, to „zdolność uczestniczenia w samym człowieczeństwie każdego człowieka”, która „warunkuje personalistyczną wartość wszelkiego działania i bytowania «wspólnie z innymi»" 83 . Czyż nie jest to filozoficzna kontynuacja ewangelicznej myśli, owego „bratania się z dziadami” z dramatu Brat naszego Boga młodego Karola Wojtyły?

\footnotetext{
78 Por. K. Wojtyła, Osoba i czyn, dz. cyt., s. 23.

79 Por. tamże, s. 328.

${ }^{80}$ Por. G. Weigel, Świadek nadziei, dz. cyt., s. 180.

${ }^{81}$ Por. K. Wojtyła, Osoba i czyn, dz. cyt., s. 315.

82 Tamże, s. 335.

${ }^{83}$ Por. tamże, s. 332.
} 
Przedmiotem studium Osoba i czyn jest osoba, która ujawnia siebie w czynie, a także swoją transcendencję ${ }^{84}$; tak jak przesłanie „bezinteresownego daru z siebie" uwiarygodnia duchowy rys ludzkiej miłości, tak również czyn osoby ludzkiej podjęty w moralnym wyzwaniu potwierdza jej transcendentny, duchowy charakter.

Podsumowując poszukiwanie filozoficznych podstaw idei rodzicielstwa duchowego, która jest głównym przesłaniem traktatu, pragnę zwrócić uwagę na komentarze włoskiego filozofa Rocca Buttiglionego, który sugeruje, że w personalizmie K. Wojtyły tkwi ,ukryta tendencja teologiczna”. W Osobie i czynie metodę analizy należy określić jako ściśle filozoficzną, ale inspiracja jest chrześcijańska. Owa tendencja realizuje się w potwierdzeniu prawa daru i prawdy o wolności jako wolności-dla-daru-z-siebie właśnie w Bogu - Trójcy Świętej „wspólnocie” oddających się „Osób”, które nie tracą niczego ze swojej jedyności przez radykalne samoudzielanie się $e^{85}$.

Swoistym uwieńczeniem treści będących podstawą rodzicielstwa duchowego w filozoficznej refleksji K. Wojtyły jest następujące spostrzeżenie „,[...] ażeby wartość zrodziła powinność, musi ona w szczególny sposób stanąć na drodze działania osoby jako swoiste wezwanie" ${ }^{96}$. Wówczas w sytuacjach naglącej potrzeby, takiej jak np. obrona dziecka, ojczyzny, Kościoła, podjęcie moralnego wezwania, a nawet wyzwania ${ }^{87}$ przejawiające się $\mathrm{w}$ dokonaniu wyboru, w czynie i postawie osoby, stają się podstawą idei rodzicielstwa duchowego. Przekraczam siebie, wzrastam jako osoba, realizując moją wolność i uzgadniając ją z dobrem i prawdą ${ }^{88}$. Przekraczam siebie, otwieram się na transcendencję, gdy nie zatrzymuję się tylko na naturze. „Bezinteresowny dar z siebie" umacnia mnie w wierności człowiekowi i Bogu, a wówczas przeżywam uczestnictwo i solidarność wielkiej rodziny ludzkiej.

W zakończeniu niniejszych rozważań należy podkreślić, że uwagi o „bezinteresownym darze z siebie" w dziele Mitość $i$ odpowiedzialność są potwierdzeniem duchowego wymiaru ludzkiej miłości, owego „boskiego rysu”, a jednocześnie esencją idei rodzicielstwa duchowego. Odkrycie i rozwój rodzicielstwa duchowego prowadzi osobę do jej rozwoju, do pełnej dojrzałości psychicznej i duchowej - do świętości.

Natomiast podjęcie moralnego wyzwania w czynie i postawie osoby jest filozoficzną podstawą idei rodzicielstwa duchowego, gdyż przejawia się ono nie tylko w szlachetnej motywacji „bezinteresownego daru z siebie”, ale w kon-

${ }^{84}$ Tamże, s. 338.

${ }^{85}$ Por. G. Weigel, Świadek nadziei, dz. cyt., s. 228.

${ }^{86}$ K. Wojtyła, Osoba i czyn, dz. cyt., s. 109.

87, ,...] skłaniać, popychać, pchać, przeć do, wyzwać, rozgrzać, rozruszać, rozpłomienić” Stownik synonimów, dz. cyt., s. 154.

${ }^{88}$ K. Wojtyła, Osoba i czyn, dz. cyt., s. 226. 
sekwentnych decyzjach i działaniach osoby. Traktat filozoficzny K. Wojtyły Osoba i czyn poprzez ukazanie transcendencji osoby w czynie pokazuje jej naturę duchową poprzez czyn moralny, wybór dobra, który jest swoistym spełnieniem osoby. Koncepcja „integracji osoby w czynie” jest kontynuacją refleksji o dojrzałości osoby przeżywającej rodzicielstwo duchowe, w przeżyciu spotkania z drugim człowiekiem oraz w solidarności z grupą i wspólnotami, w uczestnictwie, które jest zaprzeczeniem wszelkiego konformizmu. W dziele Osoba i czyn owa ,zdolność uczestniczenia w samym człowieczeństwie każdego człowieka" jest ukazana jako potwierdzenie ewangelicznego przykazania „będziesz miłował”, jako swoista empatia i dar spotkania z drugim człowiekiem. Jest ona także potwierdzeniem humanizmu chrześcijańskiego, gdyż konieczne jest wsparcie na ewangelicznym przesłaniu Jezusa Chrystusa. Wyraża się to właśnie poprzez podjęcie moralnego wyzwania w czynie i postawie przez osobę, co poprzedza odpowiedź na wartość drugiego i decyzję współdziałania na rzecz jej urzeczywistnienia.

Idea „rodzicielstwa duchowego" Karola Wojtyły, której podstawą jest podjęcie moralnego wyzwania ,przez bezinteresowny dar z siebie” w czynie i postawie przez osobę na rzecz urzeczywistnienia wartości i godności drugiego człowieka, jest swoistym przygotowaniem do ważnych wezwań zawartych w nauczaniu Jana Pawła II. Mam tu na myśli apel i zachętę do podejmowania różnych form adopcji jako odpowiedzi na wielkie współczesne problemy człowieka i rodziny. Owa idea jest także skierowana do wszystkich rodziców i wychowawców oraz podkreśla posłannictwo rodziców chrzestnych w Kościele. Dlatego może znajdować szerokie zastosowanie w głębszym rozumieniu ewangelizacji w Europie, która od czasów Oświecenia odrzuca na różne sposoby transcendencję, a z nią wiarę w przeznaczenie człowieka do życia w wieczności. „Rodzicielstwo duchowe” może realizować się w każdym wiernym, odważnym i konsekwentnym działaniu na rzecz zbawienia drugiego człowieka, każdego bliźniego. Idea rodzicielstwa duchowego zarysowana w życiu i twórczości Karola Wojtyły to pomoc w dialogu ze światem, może budować pomost w stronę wieczności, to praktyczne i realne „otwarcie drzwi Chrystusowi”.

\section{THE CONCEPT OF SPIRITUAL PARENTING IN THE LIFE AND WORK OF KAROL WOJTYŁA}

\section{Sum mary}

Karol Wojtyla's main message of spiritual parenting was influenced by the great experiences of his life, his poetic and intellectual work. The origins of the idea of spir- 
itual parenting are evident in his poetry and drama. However, it is in his intellectual work that the idea of spiritual parenting has been fully developed. The most important works were: Love and Responsibility and Person and Deed. Karol Wojtyla's book Love and Responsibility combines the idea of spiritual parenting with the "selfless gift of self," which is the essence of this idea. In the book Person and Deed, Wojtyla presents this idea in the integration of a person, through the experience of spiritual parenting manifested in solidarity with groups and communities. In Wojtyla's narrative, spiritual parenting is seen as a moral challenge. The idea of spiritual parenting depicted in the life and work of $\mathrm{K}$. Wojtyla is a help in dialogue with the world. It can be a practical and real opening of the door to Christ, the liberation of the poorest and most spiritually lost brothers and sisters.

Słowa kluczowe: rodzicielstwo duchowe; idea rodzicielstwa duchowego; bezinteresowny dar z siebie; moralne wyzwanie; pomoc w dialogu ze światem

Keywords: spiritual parenting; gift of self; moral challenge; help in dialogue with the world

\section{BIBLIOGRAFIA}

Działalność naukowa Karola Wojtyty - Centrum Myśli Jana Pawła II..., http://www. centrumjp2/ wikijp2.pl/index.php?title., s. 3 [dostęp: 23.09.2015].

Frankl V.E., Homo patiens, tłum. R. Czarnecki, J. Morawski, Wydawnictwo PAX, Warszawa 1984. Hardy R.P., Święty Jan od Krzyża: człowiek i mistyk, tłum. J. Kaszubowska, Sandomierz 2006.

Machniak J., Bóg i człowiek w poezjach K. Wojtyty, http://www.janmachniak.pl/index.php/moje-wykłady-2/53-bog-i-cz..., s. 1, 3, [dostęp: 21.09.2016].

Słownik synonimów, red. A. Dąbrówka, E. Geller, R. Turczyn, Wydawnictwo MCR, Warszawa 1996.

Szulc T., Papież Jan Pawet II: biografia, tłum. Z. Uhrynowska-Hanasz, M. Wroczyński, Wydawnictwo Prima, Warszawa 1999.

Weigel G., Kres i początek. Papież Jan Pawet II - zwycięstwo wolności, ostatnie lata, dziedzictwo, Wydawnictwo Znak, Kraków 2012.

Weigel G., Świadek nadziei. Biografia papieża Jana Pawła II, Wydawnictwo Znak, Kraków 2000.

Wojtyła K., Miłość i odpowiedzialność, red. T. Styczeń, J.W. Gałkowski, A. Rodziński, A. Szostek, Towarzystwo Naukowe Katolickiego Uniwersytetu Lubelskiego Jana Pawła II, Lublin 2010.

Wojtyła K., Osoba i czyn oraz inne studia antropologiczne, Wydawnictwo Towarzystwa Naukowego Katolickiego Uniwersytetu Lubelskiego, Lublin 2000.

Wojtyła K., Poezje i dramaty, wybór: M. Skwarnicki, J. Turowicz, red. J. Okoń, Wydawnictwo Znak, Kraków 1987.

Wojtyła K, Poezje wybrane, Ludowa Spółdzielnia Wydawnicza, Warszawa 1987.

Franciszka Roubo - absolwentka Wydziału Teologicznego Uniwersytetu im. Adama Mickiewicza w Poznaniu. Działaczka na rzecz rodziny oraz dziecka osamotnionego i osieroconego społecznie. Współorganizator Towarzystwa Przywracania Rodziny i „Poznańskiej kampanii na rzecz rodzin zastępczych”. Tworzy rodzinę zastępczą. 